\title{
Evaluation of the Association of Htr2a Gene Rs6313 Polymorphism with Heroin Dependence in a Sample from Northwest Iran
}

\author{
Fatemeh Mahmoudi $^{1}$, Leila Mehdizadeh Fanid ${ }^{2}$, Narges Zeinalzadeh ${ }^{*}$ (D), Mohammad Ali \\ Hosseinpour Feizi ${ }^{1}$
}

${ }^{1}$ Dept of Animal Sciences, Faculty of Natural Sciences, University of Tabriz, Tabriz, Iran

${ }^{2}$ Dept of Psychology, Faculty of Education and Psychology, University of Tabriz, Tabriz, Iran

\begin{tabular}{|c|c|}
\hline Article Info & A B S T R A C T \\
\hline $\begin{array}{l}\text { * Correspondence to: } \\
\text { Narges Zeinalzadeh } \\
\text { Dept of Psychology, Faculty of } \\
\text { Education and Psychology, } \\
\text { University of Tabriz, Tabriz, Iran } \\
\text { Email: nzeinalzadeh@ gmail.com }\end{array}$ & $\begin{array}{l}\text { Introduction: Heroin dependence is a chronic relapsing disorder caused by a } \\
\text { combination of genetic, epigenetic, and environmental factors. The genetic } \\
\text { contribution in the vulnerability to heroin dependence is } 40 \%-60 \% \text {. Alterations in } \\
\text { dopamine transport in the CNS are implicated in drug and alcohol dependence, } \\
\text { and according to linkage studies, the HTR } 2 A \text { rs } 6313 \text { single nucleotide } \\
\text { polymorphism plays an important role in drug dependence and abuse. This case- } \\
\text { control study aimed to investigate the association between } H T R 2 A \text { rs } 6313 \text { and } \\
\text { heroin dependence among a population from Northwest Iran. } \\
\text { Material \& Methods: The study included a sample of } 100 \text { heroin-dependent } \\
\text { patients and } 102 \text { control subjects. After DNA extraction from blood samples, the } \\
\text { genotype of } H T R 2 A \text { rs } 6313 \text { polymorphism was investigated among patients and } \\
\text { controls using the PCR-RFLP method. The obtained data were analyzed in SPSS } \\
\text { software to explore a significant association. } \\
\text { (Ethic code: } 5 / 4 / 12152 \text { ) } \\
\text { Findings: Frequencies of CC, CT, and TT genotypes were } 23 \%, 50 \% \text {, and } 27 \% \text { in } \\
\text { the patient group and } 32.35 \% \text {, } 44.12 \% \text {, and } 23.53 \% \text { in the control group. } \\
\text { According to statistical analysis, there were no significant differences between } \\
\text { case and control groups in this regard (P>0.05). } \\
\text { Discussion \& Conclusion: The results of the study could not support a significant } \\
\text { association between } H T R 2 A \text { rs } 6313 \text { polymorphism and heroin dependence in the } \\
\text { Azeri population of Northwest Iran. This indicates the need to investigate other } \\
\text { candidate genetic polymorphisms in the study population. }\end{array}$ \\
\hline
\end{tabular}

Keywords: Genetic association, Heroin dependence, HTR2A rs6313, Northwest of Iran, Serotonergic pathway

\section{$>$ How to cite this paper}

Mahmoudi F, Mehdizadeh Fanid L, Zeinalzadeh N, Hosseinpour Feizi MA. Evaluation of the Association of Htr2a Gene Rs6313 Polymorphism with Heroin Dependence in a Sample from Northwest Iran. Journal of Ilam University of Medical Sciences. November 2021;29(4): 1-7. 
افسردگى (9) و اسكيزوفرنى (·) همر اه است. با توجه به مطالعات صورت گرفته، سطوح يايين و غيرطبيعى سروتونين به توسعه اختلالات خلقى منجر مىشود و رفتارهاى بوياى ياداش را افزايش مىدهد و به حفظ رفتارهاى اعتيادآور كمكك مى كند (11)؛ ازاينرو، جندشكلى هاى زن هاى در گير در فعاليت سروتونين با تأثير براى روى سطح و فعاليت آن مى تواند كانديدهاى مناسبى براى مطالعات بيوستكى زنتيكى و وابستكى به مواد مخدر باشند. زن HTR2A يكى از زنهاى كانديد براى اين مطالعات است كه كيرنده سروتونين به نام 5-HT2A را كد

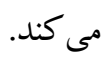
كيرنده 5-HT2A كيرندهاى جفتشونده با G-يروتئين است كه بهطور كسترده در سراسر دستخاه عصبى مر كزى يستانداران توزيعشده است و انتقال عصبى سروتونين را

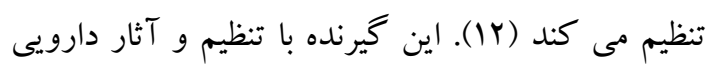
مو اد ضدافسردگىى، ضداضطراب و ضدروانيريشى مرتبط است و محل اثر مواد دارويى است (سا)؛ همجنين نشان دادهشده است كه آنتاكونيستهاى كيرندههاى سروتونين باعث تضعيف مصرف الكل در حيوانات و انسان مىشوند HTR2A (If) را بهعنوان زن كانديد براى مصرف اعتيادى مواد و الكل مطرح مى كنند (1) (1).

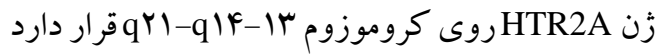
و مطالعات يِين روى دو جندشكلى تكى نو كلئوتيدى شايع آن متمركز شدهاند كه در جمعيت ارويايى در عدم تعادل بيوستگى هستند. تكك نو كلئوتيدى rs6313 يكى از اين دو جندشكلى است كه ارتباط آن با وابستكى و سوءمصرف مواد در جمعيتهاى مختلف مطالعه شده؛ اما نتايج متناقضى بهدست آمده است (ه) زن HTR2A با اينكه تو الى آمينواسيدى را تغيير نمى دهد؛ اما با كميت mRNA و يروتئين ساختهشده مرتبط است و آلل T آن با افزايش در تعداد كيرنده هاى 5-HT2A در دستگاه عصبى مركزى و آلل C، احتمالاً با بيان كمتر

\section{مقدمه}

اعتياد يكك بيمارى مزمن و عود كننده مغزى است كه در اثر تكرار مصرف مواد مخدر ايجاد مىشود و بـاعث ايجـاد آثـار نـامطلوبى جون تحمـل، وابستـى روانــى و و وابستكى فيزيكى (1) مى گردد. بر اساس تحقيقات صورت گرفته، عوامل محيطى و زنتيكى هر دو در آسيب يذيرى و گسترش اعتياد نقش دارند. بر طبق مطالعات خانوادگى، دوقلويى و فرزندخواندگى، سهم زنتيك در آسيب يذيرى به ايجاد اعتياد به مواد مخدر ·F-F •4 درصد است (Y) و از آنجاكه در بيشتر تغييرات زنتيكى كه در بروز بيمارى هاى بيجيجيده شر كت مى كنند، جندشكلى هاى تكك نو كلئو تيدى دخيل هستند، الكوى وراثتى اعتياد بهصورت اليخوزنيك مطرح است (r).

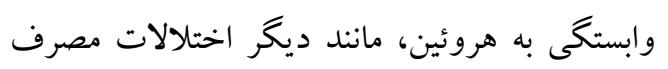
مواد، اختلال بيتيجيدهاى است كه ناشى از اثر متقابل ميان

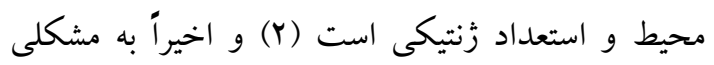

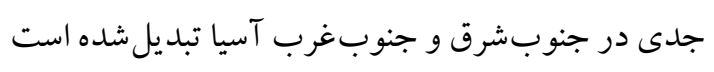
(F). با توجه به نتايج ويزوهش هاى زيست شناختى در رابطه با نقش زنتيكك در توسعه وابستخى به مواد مى توان جنين تحليل كرد كه برخى افراد با مصرف مواد مخدر تجربئ لذت بخش نادرى را كسب مى كنند و درنتيجه،

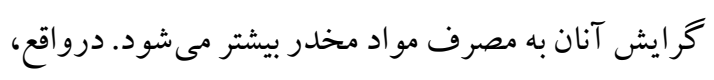

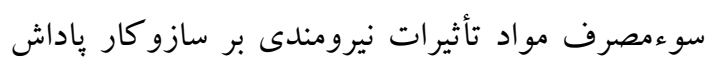
مغز و دستخاههاى انتقال دهندهُ عصبى مانند سروتونين و

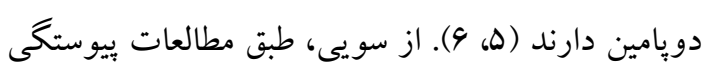
زنتيكى، تعدادى از زنهاى كانديد مشاركت كننده در استعداد ابتلا به اختلالات مصرف مواد گزارش شدهاند كه از ميان آنها مىتوان به زنهاى مسير سروتونرزيك

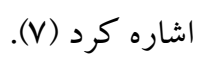

سروتونين انتقالدهندهاى عصبى است كه به علت نقش آن در بسيارى از فرايندهاى فيزيولوزيكى، جايگاه مهمى در علوم اعصاب دارد و بروز هر نوع اختلال در توليد، متابوليسم يا بازجذب سروتونين و بهتبع آن، بروز اختلال

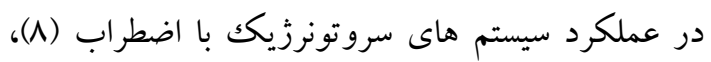


9 5'CAGAGTGTGGGTACATCAAGGTG3'

آغاز گر معكوس 5'CTAATGCCACTCACCATAC و طبق برنامهُ دمايى و زمانى به شرح ذيل استفاده

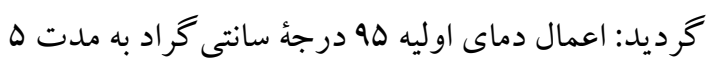
دقيقه، در ادامه ها جر خه شامل واسرشت سازى در دماى هو درجة سانتى گر اد به مدت · ب ثانيه، مرحلة اتصال در دماى بودرجة سانتى گر اد به مدت ·ب ثانيه و مرحلة بسط

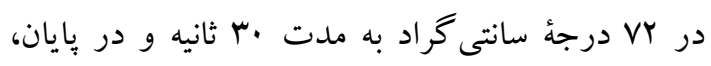
مرحلة بسط نهايى به مدت ه دقيقه در دماى VY درجة

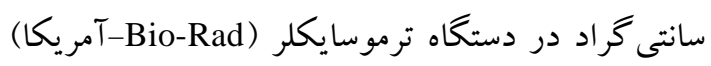

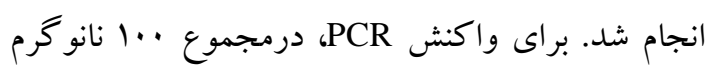
DNA بيشرو و معكوس با · ل ميكروليتر مستر ميكس PCR مخلوط كرديد و حجم آن با مانمار (- Ampliqon) آب دو بار تقطير به ·Y ميكروليتر رسانده شد. محصول

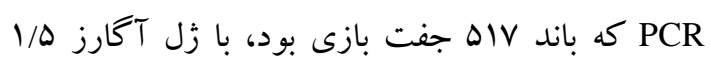
درصد بهوسيلة دستخاه زل داكك مشاهده گرديد. براى بـ باردي تعيين زنوتيب ها هضم آنزيمى نمونه ها با استفاده از آنزيم برشخر MspI آمريكا) در دماى rr درجة سانتى كر اد و به مدت ا ساعت صورت گرفت. درنهايت، محصولات هضم روى زل آكارز ه/ا درصد بار گذارى شد و نوع آلل و زنوتيِ ها تعيين گرديد (شكل شماره (). نتايج بهدست آمده با استفاده از نرمافزار ارئابى شد و داده ها با استفاده از آزمون مربع كاى دو آناليز كرديدند. قوت و شدت ارتباط ميان جندشكلى ها و خطر وابستكى به هروئين با استفاده از

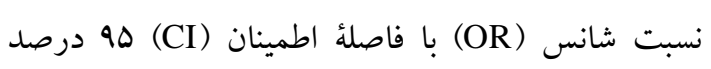

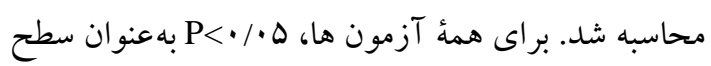
معنا دارى در نظر گرفته شد؛ همجينين براى بررسى تعادل هاردى واينبر گك در جمعيت مطالعه شده، از آزمون مربع كاى دو استفاده كرديد.

يافته ها براى تعيين زُنوتيب ها، اكر آنزيم محدود كننده
كيرنده هاى 5-HT2A و فعاليت هاى يايين تر سروتونين همراه است (19). هرجند كه بر اساس تحقيقات جديد، جندشكلى هاى تكك نو كلئوتيدى از مسيرهاى غيرمستقيم هم مى توانند بر بيان زنها تأثير بخذارند (IV)؛ اما سازو كارهاى اصلى عملكرد اين جّندشكلى روى رئ بيان يروتئين كدشونده هنوز مشخص نيست و احتمال داده مىشود كه جندشكلى rs6313 بر پايدارى mRNA خود (19) يا متيلاسيون در ناحية بروموتر زن HTR2A تأثير

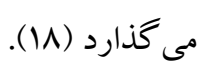
بنابراين، در مطالعهُ حاضر، نتايج بررسى همراهى

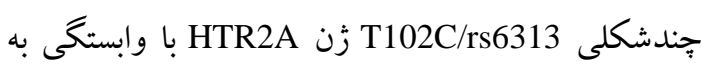
هروئين در يك جمعيت آذرى از شمالغرب ايران ارائه مى شود.

\section{مواد و روش ها} افراد مطالعهشده

در اين يثروش مورد-شاهدى، زن HTR2A در . فرد وابسته به هروئين مراجعه كننده به مركز تركك اعتياد سينا، بهعنوان گروه بيمار و همجنين Y + ا فرد سالم، بهعنوان كروه شاهد، از نظر جندشكلى rs6313/T102C بررسى ترونى زنوتيبى شدند. افراد گروه بيمار همخى مذكر با ميانخين

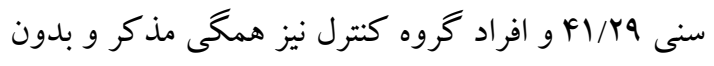
هيج كونه سابقهُ مصرف دخانيات، الكل و مواد مخدر با

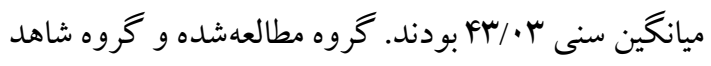
از نظر سن و جنس و قوميت باهم جور و همكى از جمعيت آذرى شمالغرب ايران بودند. براى انجام مطالعات ززنتيكى، يُشتر خون گيرى از افراد انجام شد و استخراج DNA

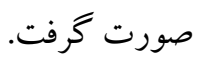
تعيين ثرنوتيب افراد و بررسىهاى آمارى تعيين زنوتيب نمونه ها با استفاده از روش جندشكلى طولى قطعات برشى (PCR-RFLP) انجام شد. براى انجام واكنش PCR از بيشرو 


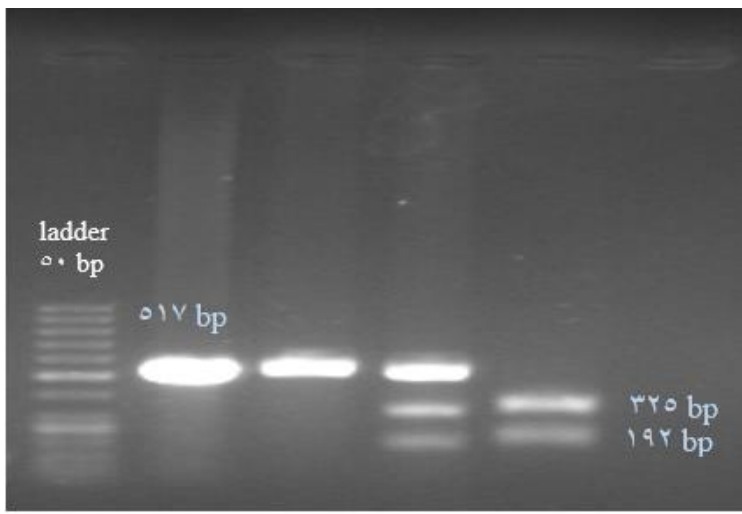

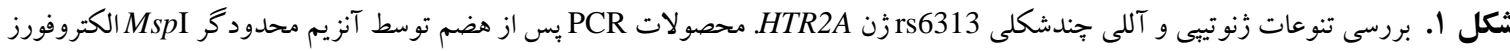

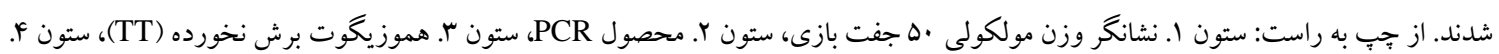

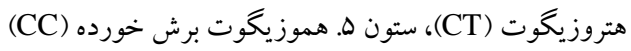

س r/هr درصد بودند و بررسى آمارى نشان داد كه ميان كروه مطالعهشده و كنترل از لحاظ فراوانى زنوتيبى، تفاوت معنادارى وجود ندارد (بسM/P=·) (جدول شماره 1). فراوانى آللى نيز ميان كروه مطالعهشده و كنترل بررسى گرديد و فراوانى آلل هاى C و T در گروه مطالعه شده به ترتيب FA و ه ه درصد و در كروه كنترل

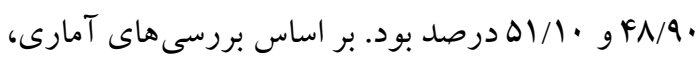
در توزيع آللى ميان كروههاى مطالعهشده و كنترل نيز

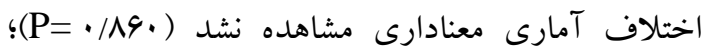
همجنين بررسى توزيع زنوتيبى در هر دو گروه كنترل و مبتلا بيانگر برقرارى تعادل هاردى واينبر گ در جمعيت مطالعه شده بود (جدول شماره ().
MspI

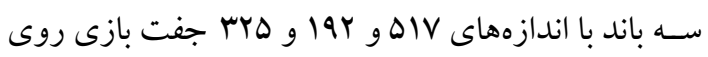

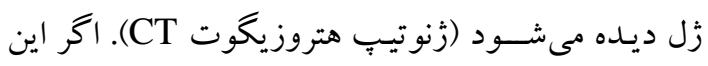
آنزيم قطعهُ مورد بررسى رادر هر دو رشته برش دهد، دو

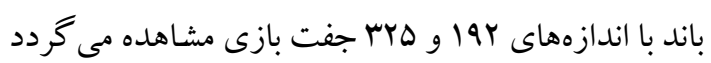
(زنوتيب هموزيخوت CC) و اكر آنزيم هيج كدام از دو رشتهٔ مورد بررسى را برش ندهد، تنها يكك باند اله جفت

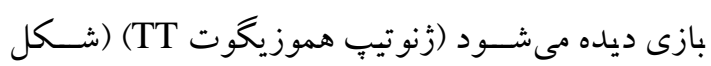

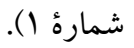

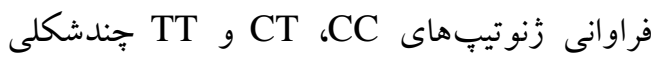
rs6313 زن HTR2A در گروه بيمار به ترتيب سب، •ه و و

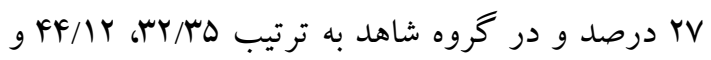
جدول ا. توزيع رنو تييى و آللى جندشكلى rs6313 زن HTR2A در ميان گروه وابسته به هروئين و گروه كنترل

\begin{tabular}{|c|c|c|c|c|c|c|c|c|c|}
\hline \multirow{2}{*}{ HWE $* * * *$} & \multirow{2}{*}{$p^{* * * *}$} & \multicolumn{2}{|c|}{ فراوانى آلل (درصد) } & \multirow{2}{*}{$p^{* * *}$} & \multicolumn{3}{|c|}{ زنوتيب (درصد) } & \multirow{2}{*}{ تعداد } & \multirow{2}{*}{ كروه } \\
\hline & & Tلل T & آل C & & $\mathbf{T} / \mathbf{T}$ & $\mathrm{C} / \mathrm{T}$ & $\mathrm{C} / \mathrm{C}$ & & \\
\hline$\cdot / 91 \mathrm{~V}$ & $\cdot / 19$ & $(\Delta Y) l \cdot F$ & $(\xi \wedge) r_{.}$ & rrr/ & $(Y V) Y V$ & $(\Delta \cdot) \Delta$. & r & $1 \ldots$ & بيمار \\
\hline س & & س $(\Delta 1 / 1)$ & $(F \wedge / q) \backslash \wedge r$ & & $(Y \mu / \Delta r) Y F$ & $(F F / M Y) F D$ & זr (ט/ & $1 . r$ & كنترل \\
\hline
\end{tabular}

HWE Hardy-Weinberg equilibrium

$* \mathrm{P}<0.05$

**The Fisher's exact p-value

***The Chi square p-value

HTR2A FF/ Y

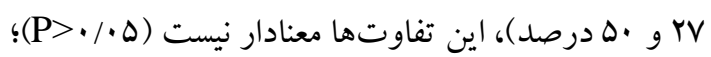
همجنين بهدست آمدن فراوانى آللى (C)

\section{بحث و نتيجه Fيرى}

نتايج بهدست آمده از يزوهش حاضر نشان داد كه با وجود تفاوت در فراوانى زنوتيبهاى هموزيخوت

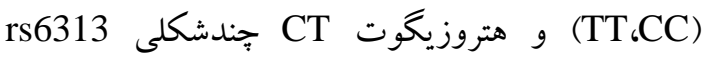




$$
\text { جندشكلى با وابستخى به الكل و هروئين است. }
$$

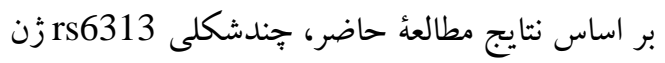

HTR2A

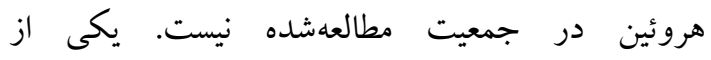

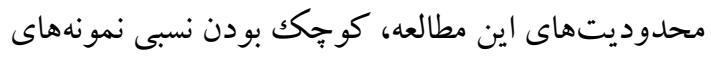

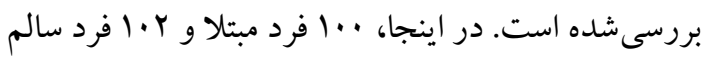

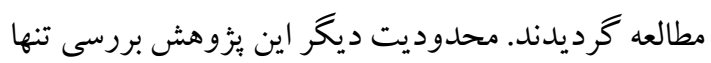

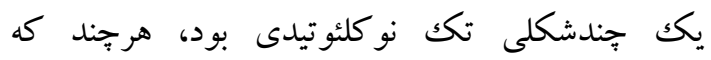

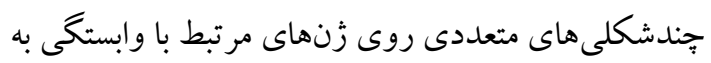
مواد وجود دارند. در كنار اين محدوديتهاى روششناختى، مطالعُ حاضر مزايايى نيز داشت؛ ازجمله

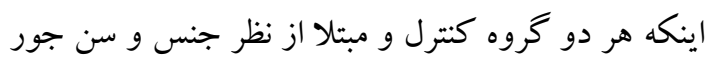

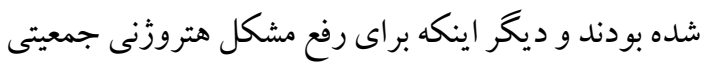
كه دربارة جمعيت كشورمان مطرح است، نمونه كيرى تنها

$$
\text { از افراد با نزاد آذرى انجام گرفت. }
$$

درنهايت، نتايج مطالعهُ حاضر بيانگر نياز ما به بررسى

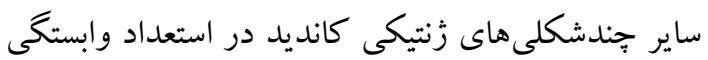
به هروئين و ساير مواد مخدر در جمعيت بررسى لهده و نيز تكرار مطالعُ حاضر در ساير نزادهاى جمعيتى كشورمان

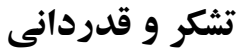

نويسند گان مقاله بر خود لازم مىداند تا از زحمات خانم بروين آذرفام كه در خونگيرى از افراد كنترل همكارى كردند و نيز همة بيماران و افراد كنترل براى همكارى صميمانهشان در بيشبرد اين كار يُزوهشى، تقدير و تشكر نمايند. مطالعة حاضر در كميته اخلاق دانشكاه

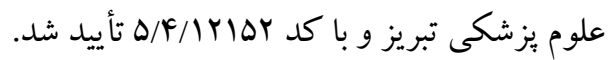

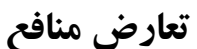

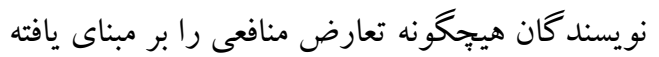

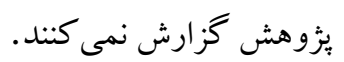

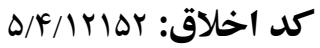

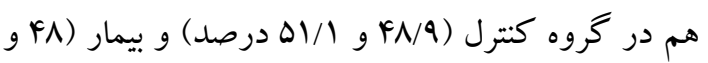
rه درصد)، نشاندهنده نبود ارتباط معنادار آمارى ميان اين آلل ها و استعداد وابستكى به هروئين است. فهر و همكاران (19) نيز كه در جمعيت آلمان، ارتباط جندشكلى rs6313 را در ميان AV فرد كنترل و و والب بيمار

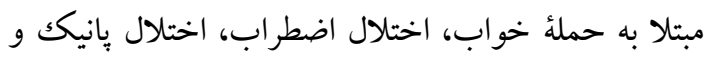

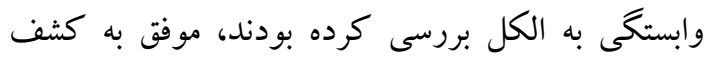

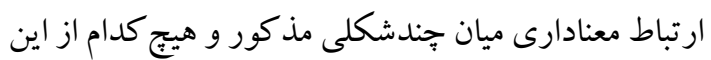

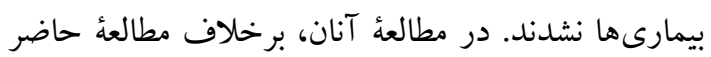

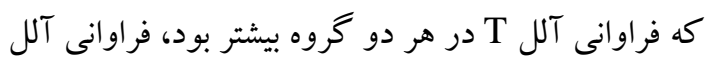
C در گروههاى گوناكون بيمارى و نيز افراد كنترل، بيشتر از آلل T گزارش شد. جاكوب زيكك و همكاران (•r) نيز

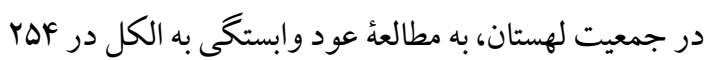
فرد وابسته در مدت يكك سال يرداختند و نشان دادند كه عود به شكل معنادارى با زنوتيّ CC مرتبط است. در يُزوهش ديخرى روى جمعيت زإين، سونو كا و همكاران (YI) به بررسى ارتباط קندشكلى مدنظر و بيمارى اسكيزوفرنى و روانيريشى ناشى از مصرف متامفتامين

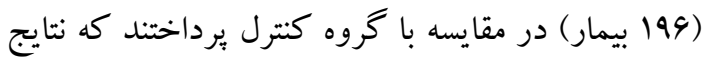
براى هر دو بيمارى بيانكر وجود نداشتن جنين ارتباطى بود.

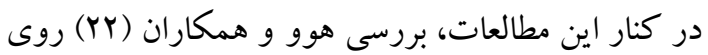

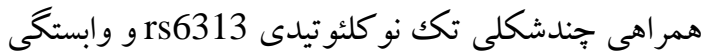

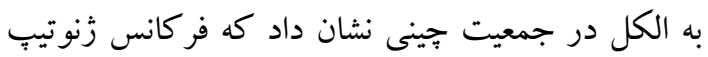
و T Tد T افراد با سوءمصرف الكل و داراى TT مشكلات رفتارى در مقايسه با گروه كنترل، به شكل معنادارى كمتر است. درنهايت، ساو و همكاران (ها) در

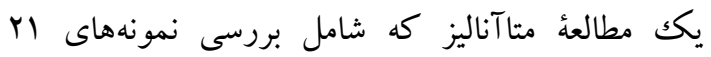

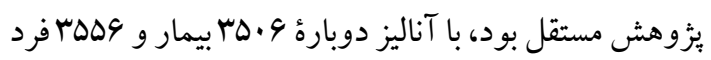
كنترل از جمعيتهاى آسيايى، ارويايى و هيسبانيك كه دونه

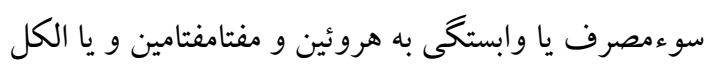

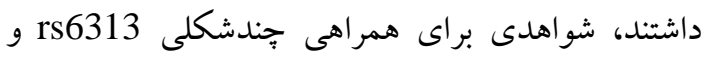

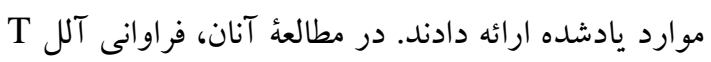

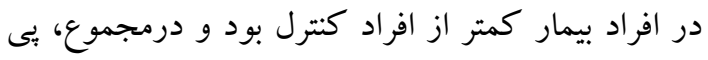

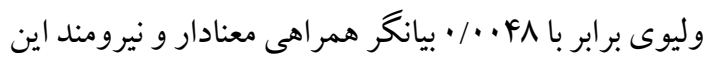




\section{References}

1. Heit HA. Addiction physical dependence and tolerance: precise definitions to help clinicians evaluate and treat chronic pain patients. J Pain Pall Care Pharmacother 2003; 17:15-29. doi.10.1080/j354v17n01_03.

2. Kendler KS, Jacobson KC, Prescott CA, Neale MC. Specificity of genetic and environmental risk factors for use and abuse dependence of cannabis cocaine hallucinogens sedatives stimulants and opiates in male twins. Am J Psychiatr 2003;160: 687-95. doi.10.1176/appi.ajp.160.4.687.

3. Goldman D, Oroszi G, Ducci F. The genetics of addictions uncovering the genes. Nat Rev Genet 2005; 6:521-32. doi.10.1038/nrg1635.

4. Kulsudjarit K. Drug problem in southeast and southwest Asia. Ann N Y Acad Sci 2004; 1025:446 -57. doi.10.1196/annals.1316.055.

5. Comings DE, Blum K. Reward deficiency syndrome: genetic aspects of behavioral disorders. Prog Brain Res 2000; 126: 325-41. doi. 10.1016/S0079-6123(00)26022-6.

6. Yeh TL, Chen KC, Lin SH, Lee IH, Chen PS, Yao WJ, et al. Availability of dopamine and serotonin transporters in opioid dependent users--a twoisotope SPECT study. Psychopharmacology 2012; 220: 55-64. doi.10.1007/s00213-011-2454-6.

7. Saiz PA, Garciaportilla MP, Florez G, Arango C, Corcoran P, Morales B, et al. Differential role of serotonergic polymorphisms in alcohol and heroin dependence. Prog Neuropsychopharmacol Biol Psychiatr 2009; 15: 695-700. doi. 10.1016/j.pnpbp.2009.03.016.

8. Akimova E, Lanzenberger R, Kasper S. The serotonin 1a receptor in anxiety disorders. Biol Psychiatr2009; 66: 627-35. doi.10.1016/j.biopsych.2009.03.012.

9. Kaye WH, Frank GK, Bailer UF, Henry SE, Meltzer CC, Price JC, et al. Serotonin alterations in anorexia and bulimia nervosa: new insights from imaging studies. Physiol Behave 2005; 85:73-81. doi.10.1016/j.physbeh.2005.04.013.

10. Grubor M, Zivkovic M, Sagud M, Perkovic MN, Mihaljevicpeles A, Pivac N, et al. Htrla ana htr1b and htr2a and htr2c and htr6 gene polymorphisms and extrapyramidal side effects in haloperidol treated patients with schizophrenia. Int J Mol Sci 2020; 28:2345. doi. 10.3390/ijms21072345.

11. Kirby LG, Zeeb FD, Winstanley CA. Contributions of serotonin in addiction vulnerability. Neuropharmacology 2011; 61: 42132. doi.10.1016/j.neuropharm.2011.03.022.

12. Hoyer D, Hannon JP, Martin GR. Molecular, pharmacological and functional diversity of 5-HT receptors. Pharmacol Biochem Behav 2002;
71:533-54. doi.10.1016/s0091-3057(01)00746-8.

13. Reynolds GP, McGowan OO, Dalton CF Pharmacogenomics in psychiatry: the relevance of receptor and transporter polymorphisms. Br J Clin Pharmacol 2014; 77:654-72. doi.10.1111/bcp.12312.

14. Pandey SC, Davis JM, Pandey GN. Phosphoinositide systemlinked serotonin receptor subtypes and their pharmacological properties and clinical correlates. J Psychiatr Neurosci 1995; 20:215-25.

15. Cao J, Liu X, Han S, Zhang C K, Liu Z, Li D. Association of the htr2a gene with alcohol and heroin abuse. Hum Genet 2014; 133: 357-65. doi.10.1007/s00439-013-1388-y.

16. Polesskaya OO, Sokolov BP. Differential expression of the $\mathrm{C}$ and $\mathrm{T}$ alleles of the 5-ht $2 \mathrm{a}$ receptor gene in the temporal cortex of normal individuals and schizophrenics. J Neurosci Res 2002; 15:812-22. doi.10.1002/jnr.10173.

17. Li Y, Shi X, Cai X, Zhu Y, Chen Y, Lai J. MicroRNA422a inhibits dcc expression in a manner dependent on snp rs12607853. Cytogenet Genome Res 2020; 160:3-71. doi. 10.1159/000506031.

18. Polesskaya OO, Aston C, Sokolov BP. Allele Cspecific methylation of the 5-ht2a receptor gene evidence for correlation with its expression and expression of DNA methylase dnmt1. J Neurosci Res 2006; 15:362-73. doi.10.1002/jnr.20732.

19. Fehr C, Schleicher A, Szegedi A, Anghelescu I, Klawe C, Hiemke C, et al. Serotonergic polymorphisms in patients suffering from alcoholism, anxiety disorders and narcolepsy. Prog Neuropsychopharmacol Biol Psychiatr 2001; 25: 965-82. doi.10.1016/s0278-5846(01)00171-3.

20. Jakubczyk A, Klimkiewicz A, Kopera M, Krasowska A, Wrzosek M, Matsumoto H, et al. The $\mathrm{cc}$ genotype in the $\mathrm{t} 102 \mathrm{c}$ htr2a polymorphism predicts relapse in individuals after alcohol treatment. J Psychiatr Res 2013; 47: 527-33. doi: 10.1016/j.jpsychires.2012.12.004.

21. Tsunoka T, Kishi $\mathrm{T}$, Kitajima $\mathrm{T}$, Okochi $\mathrm{T}$, Okumura T, Yamanouchi Y, et al. Association analysis of grm2 and htr2a with methamphetamine induced psychosis and schizophrenia in the Japanese population. Prog Neuropsychopharmacol Biol Psychiatr 2010; 30:639-44. doi.10.1016/j. pnpbp.2010.03.002.

22. Hwu HG, Chen CH. Association of 5HT2A receptor gene polymorphism and alcohol abuse with behavior problems. Am J Med Genet 2000; 4:797800. doi. 10.1002/1096-8628(20001204)96:6<797: aid-ajmg20>3.0.co;2-k. 